\title{
MYSTERY, HUMILITY AND RELIGIOUS PRACTICE IN THE THOUGHT OF ST JOHN OF THE CROSS
}

\author{
MARK WYNN \\ University of Leeds
}

\begin{abstract}
The 'dark night of the soul' is a common motif in Christian spiritual writing; and the locus classicus for this motif is the work of John of the Cross, a Spanish Carmelite friar of the sixteenth century. My aim in this paper is to use John's account of the 'night' to consider how the themes of mystery, humility and religious practice may be subsumed, and related to one another, within a Christian conception of God and of human life lived out in relation to God.
\end{abstract}

The 'dark night of the soul' is a common motif in Christian spiritual writing; and the locus classicus for this motif is the work of John of the Cross, a Spanish Carmelite friar of the sixteenth century. My aim in this paper is to use John's account of the 'night' to consider how the themes of mystery, humility and religious practice may be subsumed, and related to one another, within a Christian conception of God and of human life lived out in relation to God. ${ }^{1}$

I am going to concentrate on the two works (or two parts of the one work) in which John explores most fully the idea of the dark night, namely the Ascent of Mount Carmel and the Dark Night of the Soul. Both works were developed as commentaries on his poem 'The Dark Night'. Given the concerns of this paper, it is noteworthy that in these texts, John takes poetry rather than discursive prose to be primordially the language of religious understanding; but for present purposes, I am going to concentrate on his prosaic rendering of the import of the poem, rather than examining the poem directly.

1 The proposed theme of this collection was originally 'mystery, humility and spiritual practice' and it is for this reason that I have concentrated upon John's handling of these matters. 


\section{SOME PRELIMINARY REMARKS ON THE 'NIGHT'}

Before proceeding to a discussion of how the themes of mystery, humility and religious practice can all be expounded, and related to one another, using the motif of the 'dark night', it is important to be clear, if only in very general terms, about the nature of the 'night' on John's understanding. There are in John's work two nights: what he calls the 'dark night of the senses' comes first, and there follows the 'dark night of the spirit'. The first of these nights concerns the rooting out of improper attachments to sensory things, and the second a purification of the person's 'spirit' in relation to God. And each night has two phases, an 'active' phase, where the person's will is actively engaged in various purgative exercises, and then a 'passive' phase, where it is God who acts in the person, while their faculties remain in abeyance. The active and passive phases do not unfold in strict succession but are, rather, interwoven with one another, though it is also clear that as the person advances in the spiritual life, so their experience is increasingly one of passivity. ${ }^{2}$

From his remarks on the nature of the night of the senses at the beginning of the Ascent of Mount Carmel, it is evident that John is using the notion of 'darkness' in a variety of ways. First, as attachments to creatures, the appetites can be regarded as 'darkness'; depriving the appetites of satisfaction, and rooting them out, can also be considered as forms of 'darkness', by analogy with the way in which loss of sight plunges a person into darkness, and leaves them lacking in orientation; and lastly creatures in so far as they are 'nothing' can also be likened to darkness in so far as 'darkness is nothing. ' So sometimes it is the appetites themselves, sometimes it is their effects, sometimes it is the effects of their removal, and sometimes it is their objects which are the focus of attention, and the notion of darkness is extended, analogically, to cover each of these cases. In all of these respects, we are concerned with 'darkness' in relation to what John calls the 'faculty of the will'.

John thinks that not only the will but also the understanding is consigned to 'darkness' during the course of the 'night'. This further kind of darkness is a consequence of the fact that there is no proportion of being between creatures and God. As John says, 'the difference that lies

${ }^{2}$ See Kieran Kavanaugh's account of this point in his introduction to 'The Dark Night' in John of the Cross: Selected Writings, ed. K. Kavanaugh (New York: Paulist Press, 1987), p. 159. Hereafter this source is referred to as KK.

${ }^{3}$ See KK, pp. 64-66. 
between His divine being and their being is infinite'; and he concludes: 'Consequently, intellectual comprehension of God through heavenly or earthly creatures is impossible." So the language of darkness also serves as a way of recording the fact that in approaching God intellectually, it is necessary to lay aside all knowledge of creaturely things, since there is no route which will lead incrementally from a knowledge of these things to a knowledge of God. It is not just that knowledge of creatures is of no help in the spiritual life; on John's view, it is clear that such knowledge is apt to be a hindrance in the earlier phases of the spiritual life. As he says, 'all that can be grasped by the intellect would serve as an obstacle rather than a means to [union with God] if a person were to become attached to it. ${ }^{5}$ As well as meshing with John's account of the faculties of will and understanding in these respects, the term 'darkness' is also intended of course to carry an emotional charge: as the person encounters, or is subjected to, darkness of these various kinds, so they are liable to fall into a state of bewilderment and even of desolation.

Lastly, it is important to note that on John's account, the various phases of the night can be distinguished from one another by reference to their phenomenology. In general terms, this is because progression through the night leads the person into ever deeper forms of anguish and desolation. John's purpose in writing is to chart these various phases of the night using the language of experience: for pastoral reasons, he wants to help the novice (or their confessor) to locate their position within the night, so that they can deal appropriately with the practical and emotional challenges that are posed by that particular stage of the spiritual life, so far as that is possible. Hence much of the discussion in the Ascent and the Dark Night is cast in phenomenological terms.

This is only the briefest sketch of the character of the Dark Night, but it is enough to allow us to broach the question of how the notion of the night may be used to think through the relationship between humility, mystery and practice in the spiritual life, from the vantage point of Christian theology.

\section{HUMILITY AND THE SPIRITUAL LIFE: DARKNESS IN THE WILL}

The dark night requires, as we have seen, a rooting out of the appetites, and in this sense a purging of the will. The person can advance this

\footnotetext{
${ }^{4}$ Ibid., p. 99.

${ }^{5}$ Ibid., p. 98.
} 
process in some measure by their own labours, but these efforts at best help to prepare the way for God's activity, which is of course more fully efficacious. As John comments: 'however assiduously the beginner practises the mortification in himself of all these actions and passions of his [in the active night], he can never completely succeed - very far from it - until God shall work it in him passively by means of the purgation of the ... night.' ${ }^{3}$ In brief, then, the active night needs to be succeeded by the passive.

This development has a counterpart in feeling. The person who engages in various purgative exercises in the course of the active night will typically derive some pleasure from these activities, once they have become reasonably accomplished in performing them. But when they stand on the threshold of the passive night of the senses, these pleasures give out, and the person finds that 'not only do they experience no pleasure and consolation in the spiritual things and good exercises wherein they were wont to find their delights and pleasures, but instead, on the contrary, they find insipidity and bitterness in the said things.' The same sort of pattern, of activity and then passivity, is taken up in turn in the spiritual night; and in both cases the movement into a condition of passivity is painful and even harrowing.

These features of John's account are of some importance for an understanding of his conception of the place of humility in the spiritual life. According to John, a person's approach towards a condition of greater intimacy with God can be tracked in some measure in experiential terms. And one of his primary concerns in these works is precisely to map out that track, by drawing attention to the relevant phenomenological distinctions. But in so far as that is his strategy, he evidently risks encouraging in the spiritual novice a kind of selfsatisfaction, and even a kind of spiritual masochism. For if the novice uses John's phenomenological categories to record their progress through the spiritual life, then there is a risk that they will take pride in their growing proximity to God. And mightn't they come to enjoy, and

${ }^{6}$ This passage is taken from Saint John of the Cross, 'Dark Night of the Soul', in The Essential St. John of the Cross: Ascent of Mount Carmel; Dark Night of the Soul; A Spiritual Canticle of the Soul and the Bridegroom Christ; Twenty Poems by St. John of the Cross, tr. E. Allison Peers (Radford, VA: Wilder Publications, LLC, 2008), pp. 370-476 (p. 388). Further references to this volume will be listed as EAP.

${ }^{7}$ Ibid., p. 390. 
even to cultivate, experiences of 'darkness', in so far as those experiences are thought to betoken growing proximity to God?

A question of this general type will arise for any spiritual practice which draws distinctions between spiritually inferior and spiritually superior states of mind or activity, and which undertakes to move the novice towards a condition in which there is a preponderance of good spiritual states over bad. Any such practice will run the risk of handing over to the novice a body of information which will allow them to chart their progress through the spiritual life, and to take a degree of satisfaction in their spiritual development, and to think of themselves as superior to those ordinary folk who have not made similar progress, or who have not engaged in similar feats of spiritual discipline. Since humility must of course count as a core virtue for any Christian account of the spiritual life, there is in this respect a tension between the Christian ideal of life and the very idea of a spiritual practice.

Although he does not say as much, a great deal of John's text can be read as a sustained meditation on the question of how to combine an account of the spiritual life which distinguishes between more and less advanced conditions of 'the soul' and a commitment to humility as a core Christian value. Two central planks of this case are evident in the comments I have just cited. John does acknowledge that in the active phase of the night, the person can indeed find a measure of satisfaction in their development in the spiritual life, by applying the criteria of progress that John himself has supplied, and by taking pleasure in their growing competence in the performance of the various exercises which appear to induce progress so understood. But he is clear that this incipient selfsatisfaction cannot endure, for two reasons.

First of all, this is because the active night must give way to the passive: so whatever satisfaction the person may have found in their 'performance' in earlier stages of the night will now be lost, as they come to recognise that they cannot effect further progress by their own efforts. In these later phases of the night, it is the agency of God, rather than directly human agency, which draws the person nearer to God. Secondly, as John notes, the transition to the passive night is registered in feeling, so that the person comes to find only 'insipidity and bitterness' in the exercises in which they formerly took such pleasure. So it is not just the clear-headed recognition that it is now God's agency which is moving them through the spiritual life that prevents the person who is in the later stages of the night from deriving satisfaction from their performance 
of various spiritual practices; they also come to feel a kind of revulsion for such practices, at least to the extent that they find the prospect of engaging in them in the present repellent. And although John does not say so, we might infer that such a person is in no condition to derive satisfaction even from their past performance of such practices, however accomplished or dedicated that performance may have been.

Moreover, it is clear that for John, a central constituent of the darkness of the later phases of the 'night' is precisely the sense of having been abandoned by God: it is the felt sense of one's worthlessness before God, and of one's having being forsaken by God, that in large part comprises the desolation of the night. ${ }^{8}$ And John notes that even if the person who is enduring the passive night should be told by their director that their condition in fact signifies a deeper intimacy with God, they will be unable to believe this, such is their feeling of wretchedness, and of worthlessness before God. ${ }^{9}$ So for this reason too, the night, in its later phases especially, cannot be a source of spiritual self-satisfaction: the person who is undergoing the night cannot construe it as a mark of growing proximity to God, let alone of spiritual achievement, because the condition consists in important part in the sense of oneself as having been abandoned by God.

So in these ways, John's account remains resolutely committed to the ideal of humility: while his programme of spiritual direction does allow us to distinguish between more and less elevated spiritual states, the person who is undergoing the night cannot use this map to shore up their sense of their own importance, in ego-centric terms, because they are required to recognise that their progress (so far as there is any) is now the product of divine agency, and because they come to feel revulsion for their own efforts to advance in the spiritual life, and because the night consists in important part in the sense of one's littleness before God and even in the sense of one's having been forsaken by God. In all of these ways, John's text can be

\footnotetext{
${ }^{8}$ See John's remark that 'the soul ... believes God to be against it, and thinks that it has set itself up against God. This causes it sore grief and pain, because it now believes that God has cast it away' (EAP, p. 417). Or again, he says that such persons 'suffer great trials, by reason not so much of the aridities which they suffer, as of the fear which they have of being lost on the road, thinking that all spiritual blessing is over for them and that God has abandoned them since they find no help or pleasure in good things' (EAP, p. 395).

${ }^{9}$ See his comment: 'For, although in many ways [the soul's] director may show it good reason for being comforted because of the blessings which are contained in these afflictions, it cannot believe him.' (EAP, p. 423).
} 
read as a response to a general challenge which may be raised for the idea of a spiritual practice: in so far as it promises to improve a person's spiritual state, how is such a practice to prevent the devotee from succumbing to a sense of their 'accomplishments' in the spiritual life?

We might wonder: in that case, what is the practical point of the map of the spiritual domain that John has provided, if the person who is undergoing the night cannot use it to determine that they are being drawn closer to God? The map's purpose is, I take it, at least in part, to encourage the person of growing spiritual maturity to adopt a kind of negative practice, that is, to desist from various attempts to improve their spiritual condition by their own efforts. It is partly for this reason that John takes such care to record the signs which mark the movement from the active into the more passive phase of the night, because a key task for this transitional stage of the spiritual life is simply to accept this state of growing passivity; and if the person can do this, then their new condition may even become a source of what John calls 'inward refreshment':

If those souls to whom this comes to pass [who find themselves being drawn into the passive night of sense] knew how to be quiet at this time, and troubled not about performing any kind of action, whether inward or outward, neither had any anxiety about doing anything, then they would delicately experience this inward refreshment in that ease and freedom from care. ${ }^{10}$

So here is a form of spiritual practice which consists in part in learning how to give up all 'anxiety about doing anything' - or in learning, we might say, to 'let go' or to desist from any 'practice. The notion of a spiritual practice is in a sense being undone here. And the reasons for this are connected, once again, to John's commitment to humility as a core value of the Christian life: for if the spiritual life were, on the contrary, to be a matter of athletic self-exertion, or hard won 'success' in relation to the standards of a clearly defined practice, then it would be possible for its practitioners to revel in their achievements, and to hold others as spiritually inferior, and even as spiritually blameworthy.

John prevents such a reading of the significance of the spiritual life not only by emphasising that in its later phases this life is the work of God, and that it is necessary therefore to learn to 'let go', but also by insisting that the person must become detached even from those pleasures which have their source in God's activity and which are genuinely tokens of

\footnotetext{
${ }^{10}$ Ibid., p. 392.
} 
growing proximity to God. Thus the passage I have just cited continues: 'So delicate is this refreshment that ordinarily, if a man have desire or care to experience it, he experiences it not; for ... it does its work when the soul is most at ease and freest from care; it is like the air which, if one would close one's hand upon it, escapes.'11 So a person can experience these signs of growing intimacy with God only on condition that they have surrendered any attachment to them. And this suggests that any recipient of these tokens of divine favour will not regard them in a spirit of self-satisfaction or use them to shore up their sense of self-regard - for any such response would presumably indicate that the person had retained, after all, an attachment to these pleasures, considered as markers of their own importance. ${ }^{12}$

I have been arguing that John's emphasis on the 'passivity' of the later phases of the spiritual life serves as a buttress against the possibility of spiritual self-satisfaction or pride. Characteristically, his account of this shift, from activity to passivity, also carries an emotional charge. It's not just that the person is invited to observe themselves falling into a state of passivity, to resign themselves to that condition, and thereby to make progress in the spiritual life, while remaining free from self-satisfaction. Rather, the movement into the passive phase of the night, especially the passive night of the spirit, is experienced as bewildering and even as traumatising. Here we find a further respect in which John's picture of the spiritual life implies a deep-seated commitment to the ideal of humility.

What John is describing is the dissolution of the habits of desire and perception which formerly constituted the person's sense of self, and their gradual replacement by a new centre of personal energy, where this transition is registered in experience, from the perspective of the former self, as the onset of a kind of passivity. Crucially, John is clear that it is only when the old self has been swept away that the new self can take shape. There is therefore an interim period, which obtains after the demise of the old self and before the formation within the person of a new centre of willing and thinking. And the horrors of the 'night' arise not least when the person finds themselves in this intermediate state. In this condition, their interest in the world and their sense of their own agency have been brought to nothing, while they have, as yet, no capacity

\footnotetext{
${ }^{11}$ Ibid., pp. 392-3.

${ }^{12}$ Compare David Pugmire's discussion of 'dramaturgical' emotions: that is, emotions which are prized because of their role in shoring up a person's self-regard: Rediscovering Emotion (Edinburgh: Edinburgh University Press, 1998), p. 119.
} 
to register in experience the emergence of a new, divinely focused habit of willing and thinking. This two-step view of the spiritual life is evident in John's comment that 'the Divine fire of contemplative love ... before it unites and transforms the soul in itself, first purges it of all contrary accidents. ${ }^{13}$ Similarly, he remarks that 'God makes [the soul] to die to all that is not naturally God, so that, once it is stripped and denuded of its former skin, He may begin to clothe it anew ..... ${ }^{14}$

The term 'humility' is cognate of course with the term humus meaning ground or earth. To be humble is, then, to exist in a lowly state. And John is here suggesting that in this intermediate phase of the spiritual life, the 'soul' registers its condition in the felt recognition of its own nothingness - that is, in the feeling of its alienation from created things, and even from its own powers of activity, while it remains unable, as yet, to enjoy the new, divinely focused mode of life that awaits it. So here is a further, still deeper sense in which humility, on John's picture, is integral to the later phases of the spiritual life.

In sum, if we take up John's account of these matters, then we should say that the formation of 'humility' in the person in the course of the 'night' involves among other things the loss of all sensory satisfactions, and the loss of any capacity to undertake spiritually elevating exercises and of any desire to do so, where the self registers this loss of its former appetites, habits of willing and competences in the abject feeling of its own nothingness, and in the sense of its having been forsaken by God. In these ways, the person is brought to a condition of humility which consists fundamentally, as John says, in the 'death' of the old self considered as a bundle of attachments and projects.

It is striking that in the course of his discussion, John does not as a rule issue explicit exhortations to 'humility'. This is perhaps because such an exhortation might admit the very corruption that he is bent on resisting; for in that case, the spiritual novice might strive to make a 'success' of being humble, and might even derive some satisfaction from that 'achievement'! But while his comments do not pick out humility explicitly as a value in the spiritual life, let alone as a goal for the spiritual life, it is clear nonetheless that John's discussion of the purgation of the will can be read as a sustained meditation upon the variety of ways

${ }^{13}$ EAP, p. 433.

${ }^{14}$ Ibid., p. 445. Elsewhere, John develops the point by noting that the palate must first be cleansed before it can properly appreciate some new taste. See for example EAP, p. 392 and EAP, p. 430. 
in which development in the spiritual life, for the period of the 'night', consists fundamentally in a progressive deepening of humility, until one reaches the point where all one's satisfactions and all one's achievements, both sensory and spiritual, have been brought, from the subject's own perspective, to nought.

\section{MYSTERY, HUMILITY AND THE SPIRITUAL LIFE: DARKNESS IN THE UNDERSTANDING}

When he turns to the purgation of the understanding, John's discussion amounts once again to an affirmation of humility as a core value of the spiritual life. On one longstanding tradition, which would certainly have been known to John, it is the human person's capacity for reason which raises them above the condition of the non-human animals. ${ }^{15}$ In the 'night', however, the person's powers of reasoning, as well as their powers of willing, are brought to nothing. For John, this is not just a matter of coming to some abstractly intellectual recognition that there is no proportion between the being of creatures and of God, and that there is therefore no route leading from a knowledge of creatures to a knowledge of God. Rather, the purging of the understanding takes the form of a generalised and painful break down in the operation of reason.

John notes, for example, that the person who is entering the passive night of the senses will typically 'desire to be alone and in quietness, without being able to think of any particular thing or having the desire to do so. ${ }^{16}$ Here the person is no longer absorbed intellectually in the everyday world, and this disengagement reflects a break down in their capacity for intellectual activity, and at the same time a break down in their desire to undertake any such activity. This is incidentally one example of the deep interconnectedness of the purgation of the will and of the understanding: the incapacity to think about the everyday sensory world is born in part of a felt resistance to such activity, so that the intellectual failure is bound up with a failure in desire. Characteristically, John is careful to distinguish the case where this sort of development marks a movement into the passive night from the case where it reflects simply, say, some 'indisposition'. While an 'indisposition' is a passing

${ }^{15}$ For a particularly famous formulation of this view, which would surely have been known to John, see Aristotle, Nichomachean Ethics, reproduced in The Ethics of Aristotle: the Nichomachean Ethics, tr. J.A.K. Thomson (Harmondsworth: Penguin, 1976), Book I.

${ }^{16}$ EAP, p. 392. 
condition, the person who is genuinely entering the passive night will find that their 'inability to reflect with the faculties grows ever greater.' ${ }^{17}$

In John's terms, the soul which has entered the passive night is in a state of passive 'contemplation', where contemplation is to be distinguished from image-based 'meditation' and from discursive reasoning. He notes for example that '[f]rom this time forward, imagination and fancy can find no support in any meditation, and can gain no foothold by means thereof'. ${ }^{18}$ So although the Ascent and the Dark Night are commentaries upon the images which are set down in his poem 'The Dark Night', John is clear that, for a time at least, images as well as abstract or discursive forms of thought can no longer be relied upon to orient the person in the spiritual life. The person who is in this condition, he notes, may 'fatigue and overwork their nature, imagining that they are failing through negligence or sin. But this trouble that they are taking is,' he continues, 'quite useless, for God is now leading them by another road, which is that of contemplation. ${ }^{19}$

In these respects, the purgation of the understanding is, like the purgation of the will, integrally connected to the ideal of humility in the spiritual life: the person who is in this condition cannot find any satisfaction in their intellectual accomplishments, both because they no longer have the capacity to 'think of any particular thing' and because they have lost even the desire to do so; and we might infer that the person who is in this state is incapable of taking satisfaction even in former achievements of this kind, such is their loss of interest in such things. Here again, so far as there is a practice that is fitted for this phase of the spiritual life, it is a kind of negative practice, the practice of 'letting go', or of learning not to 'overwork one's nature'. And as with the purgation of the will, so here, we can represent the purging of the understanding as a movement into 'darkness' or 'nothingness': the mind is evacuated of imagistic and abstractly conceptual kinds of content, so that the cognitive as well as the conative forms of activity by which the self was formerly defined are brought to nothing.

The intellectual and appetitive spheres are alike in a further respect in so far as growth in the spiritual life involves in both cases not just 'darkness' but pain. Following a long-established tradition, John makes

\footnotetext{
${ }^{17}$ Ibid., p. 393.

${ }^{18}$ Ibid.

${ }^{19}$ Ibid., p. 395.
} 
this point for the intellectual sphere by supposing that development in the spiritual life can be likened to progressive exposure to light. As he says, 'because the light and wisdom of this contemplation is most bright and pure ... it follows that the soul suffers great pain when it receives it in itself, just as, when the eyes are dimmed by humours ... the assault made upon them by a bright light causes them pain. ${ }^{20}$ From his further development of this theme in this passage, it is clear that this pain is not just mental or psychological, but also has a physical dimension. However, while he follows the Platonic tradition in representing intellectual progress in the spiritual life in terms of exposure to light, it is notable that John's handling of this motif is rather different from Plato's. Plato's story of the cave has its climax in the adept's vision of the sun; and once his eyes have adjusted to its brightness, the seer is able to look directly at the sun, without being dazzled or pained by it. ${ }^{21}$ The seer then returns, of course, to the cave, whereupon he is plunged once again into 'darkness'. Indeed, on returning to the cave, the 'enlightened' person finds that, for a time, his experience is one of deepened obscurity: he finds it harder to orient himself in the realm of the shadows than do those who remained there all along. ${ }^{22}$ John seems to differ on these points.

In the Ascent and the Dark Night, John is mostly occupied with the purgative phase of the spiritual life, but in other works he speaks more fully about its consummation in the experience of union with God. But even here, his emphasis appears to be mostly upon the infusion of God's love into the person, and upon the consequent change in the appearance of the sensory world, now that it is no longer structured by appetitive concerns, rather than upon the idea that the spiritually mature person

${ }^{20}$ Ibid., p. 417.

${ }^{21}$ As Socrates says of the person who has completed the ascent to the outer world and learnt to set eyes on the sun: 'Last of [all] he will be able to see the sun, and not mere reflections of him in the water, but he will see him in his own proper place, and not in another; and he will contemplate him as he is.' See The Republic, tr. B. Jowett, Book VII, available at: <http://classics.mit.edu/Plato/republic.8.vii.html>, [accessed 4 Dec 2011].

${ }^{22}$ As Socrates says: 'Imagine once more, I said, such an one coming suddenly out of the sun to be replaced in his old situation; would he not be certain to have his eyes full of darkness?' He continues: 'And if there were a contest, and he had to compete in measuring the shadows with the prisoners who had never moved out of the den, while his sight was still weak, and before his eyes had become steady (and the time which would be needed to acquire this new habit of sight might be very considerable) would he not be ridiculous?' (The Republic, Book VII) 
'sees' the light of the divine nature. As Rowan Williams remarks, when speaking of John's work the Spiritual Canticle:

The sense of God living constantly in the soul, of God's goodness in all things, of the warmth of reciprocal love - all these things of which the Canticle speaks at length are described not at all in terms of revelations granted in ecstasy, but in terms of a general disposition or attitude of the soul, a regular daily mode of seeing and understanding, a new light on things. ${ }^{23}$

So while John does allow that the person of growing spiritual maturity can become accustomed to spiritual light, so that they no longer feel pained by it, he does not follow Plato in describing the summit of the spiritual life, ante-mortem, as fundamentally a matter of 'seeing' God or the divine Light. And no doubt he is moved here once more by his commitment to the idea that 'the difference that lies between [God's] divine being and [the being of creatures] is infinite. So in this sense, for John, the mystery of God is a fundamental datum of the spiritual life, and this truth holds for the 'enlightened' believer as for others.

Moreover, while in Plato's story the seer is consigned to deepened obscurity on returning to the realm of the senses, or 'the cave', on John's account, the person of spiritual maturity will find, following the night, that the sensory world is not so much obscured as transfigured. The emphasis in John's thought is, then, as Williams implies, not so much upon seeing the light or the 'sun' of the divine nature, as upon seeing the world anew, once it is illuminated by that light. In the Dark Night, John puts this point in these terms:

[S]ince this spiritual light is so simple, pure and general, not appropriated or restricted to any particular thing that can be understood, whether natural or Divine (since with respect to all these apprehensions the faculties of the soul are empty and annihilated), it follows that with great comprehensiveness and readiness the soul discerns and penetrates whatsoever thing presents itself to it, whether it come from above or from below. ${ }^{24}$

${ }^{23}$ Rowan Williams, The Wound of Knowledge: Christian Spirituality from the New Testament to Saint John of the Cross (Cambridge, MA: Cowley Publications, 1991), pp. 187-188.

${ }^{24}$ EAP, pp. 427-8. I take it that for John God is not a 'particular thing', and that he does not intend to refer to God by the expression 'Divine thing'. 
Here, it's not the light source that is viewed in the condition of 'enlightenment', but the things which 'present' themselves to the soul, in so far as they are illuminated by that source. So John's view seems to be that the sensory world can be newly experienced following the purgation of the will and the understanding: at this point, we might say, its appearance is no longer structured according to any appetitive interest in its contents. ${ }^{25}$ The difference between John and Plato on this point is reflected in their choice of metaphors. Plato represents the sensory world as a 'cave', and caves while they remain caves are never going to be illuminated by the light of the sun: they will always be places of darkness. By contrast, when John speaks of 'darkness' he has in mind a condition of the person, rather than a condition of the sensory world in itself. Thus in his discussion, John is concerned with the person whose 'eyes are dimmed by humours', and he speaks of the soul which is 'assailed' by the divine light as 'dark and impure. ${ }^{26}$ In speaking in these terms, John is adhering of course to the traditional Christian affirmation of the goodness of creation, and to the associated thought that creatures constitute an 'impediment' to relationship to God not in themselves, but only in so far as we become 'attached' to them. ${ }^{27}$ So in his development of the light motif, John is in effect setting out in an experiential idiom a distinctively Christian conception of the mystery of God, the goodness of creation, and the corruption of the will.

John provides a pithy even if rather riddling summary of the various themes that we have been examining in some remarks which he clearly intended to stand at the very beginning of the Ascent of Mount Carmel. ${ }^{28}$ He writes:

To come to the knowledge of all desire the knowledge of nothing /

${ }^{25}$ Compare for example the phenomenological emphasis of the following passage. Here John is talking of the passive night of the spirit: 'At ... times [the soul] wonders if it is under a charm or a spell, and it goes about marvelling at the things that it sees and hears, which seem to it very strange and rare, though they are the same that it was accustomed to experience aforetime. The reason of this is that the soul is now becoming alien and remote from common sense and knowledge of things, in order that, being annihilated in this respect, it may be informed with the Divine ...' (EAP, p. 431).

${ }^{26}$ Ibid., p. 417.

${ }^{27} \mathrm{KK}$, p. 66.

${ }^{28}$ These comments appear on his diagrammatic representation of the ascent of Mount Carmel. Kieran Kavanaugh's discusses the role of the diagram in KK, p. 43. The diagram is reproduced in KK, pp. 44-45. 
To come to possess all

Desire the possession in nothing /

To arrive at being all

Desire to be nothing

The insistent repetition of 'nada, nada, nada' here hammers home the point: the precondition of spiritual awakening is, to put the same thought in varying ways, the annihilation of the faculties (both of 'knowledge' and of 'desire'), the death of the old self and its habits of believing and willing, and the bringing of the person to a felt recognition and acceptance of their own nothingness. Or to consider the matter from the other side of this transformation, once the person has reached this condition, then their will can be united with the divine will; and then they can see things according to a divinely ordered scale of values, and enter thereby a new perceptual world. Viewed from this further perspective, the person is not so much 'nothing', as 'all'. Given its location at the head of his text, it is reasonable to take the passage from which I have just quoted as an interpretive key for the Ascent and the Dark Night. So it is striking that this passage closes with these words: 'In this nakedness the spirit finds its rest, for when it covets nothing, nothing raises it up, and nothing weighs it down, because it is in the center of its humility. ${ }^{29}$ Here we find John professing in his own terms that the sine qua non of the spiritual life is humility.

In sum, if we were to ask John how we should understand the contribution of humility, mystery and practice to the spiritual life, then, on the evidence of these texts, we would expect him to reply in broadly these terms. First, what is the role of humility in the spiritual life? To put the point briefly, humility is a core virtue of the spiritual life because spiritual maturity requires the person to pass through an intermediate zone, wherein the old self and its habits of willing and believing have been reduced to 'nothing'; while this condition is enduring, the pain which it causes initially will cease as the adept comes to be animated by a divinely infused and divinely focused habit of willing and believing. And what, then, is the role of mystery in the spiritual life? In brief, because of the disproportion between the being of God and the being of creatures - or because of what we might call the divine 'mysteriousness' intellectual development in relation to God cannot take the form simply of building incrementally upon our knowledge of creatures. Instead,

\footnotetext{
${ }^{29}$ Ibid., p. 45.
} 
we are required to set this knowledge at nought; and this condition is registered experientially, in the intermediate phase of the spiritual life, in the breakdown of conventional forms of thinking and, once again, in the abject feeling of one's nothingness. But once this phase has passed, then it is possible to see creatures as illuminated by the divine Light though here again there is mystery, to the extent that this condition is to be distinguished from that of seeing the divine Light itself. And finally, what is the role of practice in the spiritual life? In brief, there are various kinds of practice, each fitted for a different stage of the spiritual life. And we need therefore to distinguish between the active participation in spiritual exercises which is required in the earlier phases of the spiritual life, the 'passive' practice of 'letting go' which defines the middle phase of the spiritual life, and then the renewed activity of intellect and of egotranscendent desire that is appropriate for the final phase of the spiritual life, once things are seen and desired in God or according to a divinely focused scheme of values.

\section{JOHN AND CHRISTIAN TRADITION}

To bring out the import of John's reflections on the spiritual life from another vantage point, I am going to try now, very briefly, to relate his thought to some wider themes in Christian theology. To make this a practicable task, I shall concentrate on the idea that John's reflections can be read as an experiential rendering of various motifs which appear in a more austerely analytical idiom in the work of Thomas Aquinas.

Having studied theology at the University of Salamanca, John would have been familiar with Aquinas's work. ${ }^{30}$ And he would surely have known Thomas's remark, which stands as the preface to his treatment of the idea of divine simplicity, that 'we cannot know what God is, but only what he is not. ${ }^{31}$ John's discussion of the breakdown in imagistic and discursive thinking which arises in the middle phase of the spiritual life could be read as a record of this same idea in an experiential idiom. And John seems to be echoing Thomistic themes once again when he turns to consider the renewal of the senses which follows the 'night'. In The Living Flame of Love, he writes of this state in these terms:

\footnotetext{
${ }^{30}$ As Peter Tyler notes, there is some dispute about the extent to which John's work reveals the influence of Aquinas: Peter Tyler, Saint John of the Cross (London: Continuum, 2010), p. 17. But that there is some influence is undeniable.

${ }^{31}$ Aquinas, Summa Theologiae, 1a. 3.
} 
Though it is true that the soul here sees that all these things are distinct from God, in that they have a created existence ... it knows also that God in His own essence is, in an infinitely preeminent way, all these things, so that it understands them better in Him, their first cause, than in themselves. This is the great joy of this awakening, namely to know creatures in God, and not God in His creatures: this is to know effects in their cause, and not the cause by its effects. ${ }^{32}$

In this passage, John is alluding, I take it, to the distinction which Aquinas draws, in his preamble to the Five Ways, between a demonstration 'propter quid' and a demonstration 'quia.' ${ }^{33}$ Thomas is of course of the view that a purely philosophical approach to the question of God must begin with the observation of creatures, and move from there to the idea that there is a God, by establishing that the world stands in need of a cause. This is to take the route of a 'demonstratio quia'. Since we 'do not know what God is', we have no capacity, when we are reasoning in purely philosophical terms, to proceed in the other direction, by starting from a knowledge of God's essence, and arriving on that basis at a conception of God's effects. When he says that we can 'know creatures in God', and that 'this is to know effects in their cause, and not the cause by its effects', John is in effect saying that where the spiritual life is concerned, we can live according to the ideal of 'proper quid': that is, we can start from the divine perspective on things, and move out from there to an appreciation of the realm of creatures. But he also acknowledges of course that this is not the natural human condition, and that reaching such a perspective will be a costly process. Here John seems to echo quite deliberately Aquinas's teaching, but at the same time to extend it, by adopting, once more, an experiential standpoint: if not philosophically, then at any rate experientially, we can take the divine perspective as our starting point, once we have been brought to the later phases of the spiritual life.

When we turn to the theme of love, it appears that at times it is, on the contrary, Aquinas who begins from the divine perspective, while John's tendency is to start out from the human vantage point. In general, the emphasis in Aquinas's work is upon 'grace perfecting nature. ${ }^{34}$ And we

${ }^{32}$ The Living Flame of Love by Saint John of the Cross with his Letters, Poems, and Minor Writings, tr. D. Lewis (London: Thomas Baker, 1919), Commentary on Stanza IV, p. 121.

${ }^{33}$ Summa Theologiae, 1a. 2. 2.

${ }^{34}$ See for example Thomas's idea that the powers which are 'connatural' to the sacramental elements are not displaced or annihilated but instead inserted within a larger, God-directed teleology. He makes this point for the case of baptism in Summa 
might see this motif as one way of recording the operation of divine love: this love, like forms of love with which we are familiar from the human domain, seeks to affirm and extend or 'perfect' the beloved, rather than bring them to a sense of their own 'nothingness' or worthlessness. By contrast, John's experiential starting point means that his focus is upon the human person's experience of an emerging love for God. And for the person in the night, this developing love for God may seem to involve not so much the consolidation or extension of established habits and powers, as an overturning or eradication of those powers. A mother's emerging love for her new-born child provides perhaps a rough analogy for this sort of experience. As we all know, this love can be experienced as deeply disorienting. And we might suppose that this is not least because it can seem to require (and really can require) a radical re-ordering, and even an uprooting, of established attachments, so that the mother's sense of herself is fundamentally re-defined. For these reasons, a woman's nascent love for her child can sometimes be registered in experience as bewildering and even as 'dark' in something like John's sense. So in these matters too, John's account has a rather different cast from Aquinas's; and this reflects once again his adoption of an experiential standpoint.

John's distinction between the active and passive phases of the 'night' can also be read as an allusion, in an experiential mode, to certain ideas which Aquinas develops in his own, more analytical idiom. As is well known, Thomas thinks that if a person is to be properly oriented towards God, then they need more than simply the 'acquired' moral virtues, that is, those moral virtues which derive from human effort and a process of habituation. Along with these virtues, they also need the 'infused' moral virtues and the theological virtues, both of which are communicated to the person directly by God. So for Aquinas, there is no incremental route leading from those patterns of activity to which we are accustomed simply as human to those patterns which will fit a person, in full, for relationship to God; to make this transition, a radically new, divinely infused spring of action is required, rather than simply the further exercise of established habits of willing and action. In John's scheme, something like this idea appears in an experiential guise in his suggestion that in the later phases of the spiritual life, the person's experience is increasingly one of passivity. Old attachments and habits fall away, and in their place

Theologiae, 3a. 62. 1 ad 2, in Summa Theologiae, Vol. 56, The Sacraments, tr. D. Bourke (Blackfriars: Eyre \& Spottiswoode, 1975). 
there emerges, gradually, a new, divinely infused mode of activity; and so far as it persists at all, the old self registers these developments in the felt recognition of its own passivity.

To put the point otherwise, we could say that in speaking of the 'active' phase of the 'night', John is affirming the role of the acquired virtues, and that in speaking of its 'passive' phase, he also allows a role for the 'infused' virtues. So here again, a theme which Aquinas develops by appeal to the relevant analytical distinctions finds a phenomenological counterpart in the work of John, although it is evident once more that John's thought has an antithetical cast that is lacking in Aquinas, in so far as he leads his reader to suppose that the powers which are exercised in the 'active' phase of the 'night' have to be cast aside as the person is drawn more deeply into the passive night, rather than simply being extended or supplemented in some fashion.

So in their remarks on the limits of our knowledge of God, the nature of love, and the relationship between divine and human forms of agency, John and Thomas both address the role of mystery, humility and practice in the spiritual life. But evidently, they treat these themes from rather different vantage points and in terms of their rather different idioms. Given the closeness of his relationship to Aquinas on these questions, it is clear that John is not writing as an eccentric, but as a theologian whose insights are recognisably continuous with the mainstream of Christian tradition, while at the same time he is creatively extending that tradition, above all through his adoption of an experiential standpoint.

\section{CONCLUSION: JOHN AND THE SPIRITUAL LIFE TODAY}

Even allowing for the continuity between his reflections and those of a figure as central to the Christian tradition as Thomas Aquinas, we might still wonder whether John's discussion can contribute much to a contemporary, twenty-first century understanding of the spiritual life. In concluding, let me touch very briefly on this question.

John of the Cross was a spiritual director of wide experience, and the process of development which he describes in the Ascent and the Dark Night was presumably one which he encountered with reasonable frequency in the lives of the friars, nuns and others who came to him seeking spiritual counsel. It is possible that the particular pattern of psychological change which he describes was in some way dependent on the specific conditions of life in the sixteenth century, or perhaps more 
exactly on life as a Carmelite friar or nun in the sixteenth century. But this seems doubtful, not least because so many Christians, lay as well as ordained, in later centuries as well as in John's time, have found his account of the spiritual life to fit their own experience, or at any rate to illuminate that experience in significant respects. ${ }^{35}$ Allowing for this, it might still be said that John's account is only going to make good sense to those who are willing to share his theistic construal of the developments which he describes. But that too may be doubted. What John is recording is, it seems, the moral and, from his point of view, the more-than-moral transformation of the human person; and his interest, in the Dark Night especially, is in the middle ground of this transformation, when the familiar patterns of desire and activity that sustained the old sense of self are being eroded, or have been kicked away, and have yet to be replaced by a new centre of thought and action. So he is interested in a problem of quite general significance: the problem of how to effect, or how to participate in, a pervasive re-definition of the self and its habits of desire and perception, and how to negotiate the period of disorientation that seems bound to form part of any such process of self-redefinition.

And what of God in all of this? When 'the soul' finds itself in the passive night of the spirit, John notes, it is unable to raise its affection or its mind to God, neither can it pray to Him....36 And he continues: 'In truth this is no time for the soul to speak with God; it should rather put its mouth in the dust, as Jeremias says, so that perchance there may come to it some present hope, and it may endure purgation with patience. ${ }^{37}$ Manifestly, in this phase of the spiritual life at least, God is not encountered as an object of experience, nor postulated as an explanation, nor even addressed in prayer, but acknowledged only, if at all, in disorientation and confusion - and in the dogged anticipation of a renewal of hope. This is not a conception of what it is to believe in God, or to keep faith in God, that is much current in discussions in the philosophy of religion. And it may be, then, that John has something to teach philosophers of religion, not only about 'spiritual' matters, but also about the variety of forms which religious belief may take, even within the span of a single life.

${ }^{35}$ However, it is worth remembering that according to John, the 'night of the spirit is the portion of very few', although the night of sense is 'common' (EAP, p. 389).

${ }^{36}$ Ibid., p. 426.

${ }^{37}$ Ibid. 